\title{
Pengaruh Lama Fermentasi terhadap Kualitas Pupuk Bokashi Padat Kotoran Sapi
}

\author{
Maria Lurdes Lika Tallo ${ }^{\mathrm{a}}$, Stefanus Sio ${ }^{\mathrm{b}}$ \\ ${ }^{a}$ Fakultas Pertanian, Universitas Timor, Kefamenanu, TTU - NTT, Indonesia, email: talloudis@gmail.com \\ ${ }^{b}$ Fakultas Pertanian, Universitas Timor, Kefamenanu, TTU - NTT, Indonesia, email: Stefsio67@ gmail.com
}

\section{Article Info}

\section{Article history:}

Received 22 Desember 2018

Received in revised form 12 Januari 2019 Accepted 25 Januari 2019

DOI:

https://doi.org/10.32938/ja.v3i1.646

\section{Keywords:}

Kompos

Guano

Turi

\begin{abstract}
Abstrak
Tujuan dari penelitian ini untuk mengetahui untuk mengetahui waktu fermentasi terhadap kualitas pupuk bokashi padat kotoran sapi Penelitian berlangsung di Fakultas Pertanian Universitas Timor selama 3 bulan dengan bahan yang digunakan adalah feses sapi kering, daun gamal, dedak padi, air, gula, EM4, sedangkan alat yang digunakan adalah skop, timbangan, gayung, ember, terpal, karung, termometer dan $\mathrm{pH}$ meter. Metode yang digunakan dalam penelitian ini adalah rancangan acak lengkap (RAL) terdiri dari 4 perlakuan dan 4 ulangan; R0 : bokashi difermentasi selama 14 hari, R1 : bokashi difermentasi selama 21 hari, R2 : bokashi difermentasi selama 28 hari, R3 : bokashi difermentasi selama 35 hari sedangkan variabel yang dilihat adalah kualitas fisik (aroma, tekstur dan warna) dan kualitas kimia (N, P, K, dan Rasio $\mathrm{C} / \mathrm{N}$ dan $\mathrm{pH}$ ). Data yang di peroleh diolah dengan menggunakan sidik ragam sesuai Rancangan Acak Lengkap (RAL) dan uji lanjut dengan menggunakan Uji Jarak berganda Duncan untuk melihat perbedaan. Hasil menunjukkan bahwa warna yang dihasilkan adalah berwarna cokelat sampai cokelat kehitaman, beraroma tanah, bertekstur halus, $\mathrm{pH}$ normal sedangkan kualitas kimia yang dihasilkan termasuk dalam kategori bokashi yang ideal. Disimpulkan bahwa lama fermentasi pupuk bokashi padat yang berbeda-beda memberikan pengaruh terhadap karakteristik fisik (warna, aroma, tekstur) dan kimia $(\mathrm{N}, \mathrm{P}, \mathrm{K}$, Rasio $\mathrm{C} / \mathrm{N}$ dan $\mathrm{pH}$ ) pupuk bokashi padat kotoran sapi. Pupuk bokashi yang paling baik adalah dengan lama fermentasi 35 hari
\end{abstract}

\section{Pendahuluan}

Pupuk adalah suatu bahan yang digunakan untuk mengubah sifat fisik, kimia atau biologi tanah sehingga menjadi lebih baik bagi pertumbuhan tanaman Jenis pupuk sendiri jika dilihat dari senyawa penyusunnya dibagi menjadi dua yaitu pupuk organik dan pupuk anorganik. Pupuk organik adalah nama kolektif untuk semua jenis bahan organik asal tanaman dan hewan yang dapat dirombak menjadi hara tersedia bagi tanaman. Pupuk organik yang baik adalah pupuk yang mengutamakan kandungan $\mathrm{C}$-organik sehingga dapat menghasilkan nilai $\mathrm{C} / \mathrm{N}$ rasio yang rendah. Untuk pencapaian $\mathrm{C} / \mathrm{N}$ rasio serta kandungan Nitrogen $(\mathrm{N})$, Fosfor $(\mathrm{P})$ dan Kalium $(\mathrm{K})$ yang sesuai standar dapat dilakukan dengan membuat pupuk organik melalui proses dekomposisi dengan bantuan energi yang berasal dari fermentasi mikroba yang disebut Effective Microorganisms (EM4). Pupuk organik dengan memanfaatkan EM4 sering disebut dengan pupuk Bokashi. Komposisi bahan-bahan organik pembuatan Bokashi yang digunakan dalam penelitian ini adalah kotoran sapi dan daun gamal. Digunakan kedua bahan tersebut dikarenakan kedua bahan berpotensi baik dalam segi kualitas maupun kuantitas.

Menurut Effi (2004), pupuk kandang merupakan pupuk organik dari hasil fermentasi kotoran padat dan cair (urine) hewan ternak. Pupuk kandang mengandung unsur hara makro yang dibutuhkan tanaman seperti Nitrogen $(\mathrm{N})$, Fosfor (P), dan Kalium (K) serta mengandung unsur mikro seperti Kalsium (Ca), Magnesium (Mg), dan Sulfur (S). Penggunaan pupuk kandang memerlukan perhatian yang serius karena kandungan unsur haranya yang bervariasi Komposisi hara ini sangat dipengaruhi oleh beberapa faktor seperti jenis, umu hewan, jenis makanannya, alas kandang, dan penyimpanan. Cara memperoleh bokashi yang baik adalah dengan mengaktifkan perkembangan bakteri yang melakukan penghancuran terhadap bahan-bahan organik dalam waktu yang singkat, dan menghindarkan faktor-faktor yang dapat mengurangi kualitas bokashi. Diharapkan dengan pemberian pupuk yang mengandung mikroorganisme, proses pembokashian dapat dipercepat. Lama fermentasi pupuk bokashi padat dapat memberikan pengaruh yang baik terhadap kualitas, warna dan tingkat konsentrasi bokashi. Pemberian bokashi yang difermentasikan dengan EM4 merupakan salah satu cara untuk memperbaiki sifat fisik, kimia dan biologi tanah serta dapat menekan hama dan penyakit serta meningkatkan mutu dan jumlah produksi tanaman (Nasir, 2008).

\section{Metode}

Penelitian ini telah dilaksanakan di Fakultas Pertanian Universitas Timor, Kelurahan Sasi, Kecamatan Kota Kefamenanu, Kabupaten Timor Tengah Utara dari bulan September-November 2018. Bahan yang digunakan adalah feses sapi kering, daun gamal, dedak padi, air, gula, EM4, sedangkan alat yang digunakan adalah skop, timbangan, gayung, ember, terpal, karung, termometer dan $\mathrm{pH}$ meter. Metode yang digunakan dalam penelitian ini adalah metode eksperimen dengan menggunakan rancangan acak lengkap (RAL) terdiri dari 4 perlakuan dan 4 ulangan :

R0 : bokashi difermentasi selama 14 hari

R1 : bokashi difermentasi selama 21 hari

R2 : bokashi difermentasi selama 28 hari

R3 : bokashi difermentasi selama 35 hari

Pembuatan bokashi dilakukan dengan mencacah daun gamal dengan ukuran $\pm 5-10 \mathrm{~cm}$, kemudian melarutkan gula ke dalam air dan setelah itu memasukkan larutan EM4. Kemudian membuat lapisan pertama dari tumpukan daun gamal yang sudah dicacah $\pm 15 \mathrm{~cm}$, lapisan ke dua letakan pupuk kandang yang sudah dihancurkan, kemudian pada lapisan ketiga letakan dedak padi secara merata, setiap lapisan disirami air yang sudah dicampur dengan gula dan EM4, setelah itu ditutup rapat dengan terpal lalu diamati perubahan yang akan terjad per 8 jam kemudian diaduk dengan mengaduk-aduk campuran bokashi, dan diukur suhu sebelum dibalik. Fermentasi akan terjadi ditandai dengan naiknya suhu, suhu harus dijaga jangan lebih dari $50^{\circ} \mathrm{c}$, dengan cara membuka tutup tumpukan bahan bokashi dan mengaduk-aduk kembali. Data diambil sesuai waktu fermentasi yang ditentukan yaitu selama 14, 21, 28 dan 35 hari. Pengamatan fisik yang terdiri dari, aroma, tekstur dan warna dilakukan menggunakan panelis dengan memberikan poin (1-5). Setelah semua pengamatan fisik dilakukan maka sampel diambil dan di bawah ke laboratorium untuk dianalisis kandungan kimianya (N, P, K, dan Rasio C/N dan $\mathrm{pH}$ ).

Data yang di peroleh diolah dengan menggunakan sidik ragam sesuai Rancangan Acak Lengkap (RAL) dan uji lanjut dengan menggunakan Uji Jarak berganda Duncan (Stell dan Torrie, 1991) untuk melihat perbedaannya.

\section{Hasil dan Pembahasan}

\subsection{Warna Bokashi}

Dalam penilaian kualitas fisik (warna, aroma dan tekstur) bokashi maka pengamatan diberi skoring dari 1-5. Warna Bokashi merupakan salah satu parameter yang mencirikan proses fermentasi berjalan dengan baik atau tidak dalam pembokashian. Proses fermentasi merupakan penguraian bahan organik dengan bantuan mikroorganisme, dimana bokashi yang semakin lama difermentasi cenderung menghasilkan warna yang lebih gelap. Hasil penilaian warna bokashi dapat dilihat pada Tabel 1 .

Tabel 1. Rataan Warna Bokashi yang Difermentasi dengan Waktu Berbeda

\begin{tabular}{|c|c|c|c|c|c|c|}
\hline \multirow{2}{*}{ Perlakuan } & \multicolumn{4}{|c|}{ Ulangan } & \multirow{2}{*}{ Jumlah } & \multirow{2}{*}{ Rataar } \\
\hline & 1 & 2 & 3 & 4 & & \\
\hline R0 & 3,00 & 3,40 & 3,20 & 3,20 & 12,80 & $3,20^{\mathrm{d}}$ \\
\hline $\mathrm{R} 1$ & 3,60 & 4,00 & 3,80 & 3,60 & 15,00 & $3,75^{\mathrm{c}}$ \\
\hline $\mathrm{R} 2$ & 4,00 & 4,20 & 4,00 & 4,40 & 16,60 & $4,15^{\mathrm{b}}$ \\
\hline R3 & 4,80 & 4,80 & 5,00 & 4,60 & 19,20 & $4,80^{\mathrm{a}}$ \\
\hline Jumlah & 15,40 & 16,40 & 16,00 & 15,80 & 63,60 & \\
\hline
\end{tabular}

Ket: Angka yang diikuti superskrip yang berbeda menunjukkan pengaruh nyata $(P<0,05)$

Dari Tabel 1 menunjukkan bahwa warna bokashi dengan waktu fermentasi berbeda memberikan nilai tertinggi pada perlakuan R3 $(4,80)$, diikuti perlakuan R2 $(4,15)$ kemudian R1 $(3,75)$ dan yang terendah pada perlakuan R0 $(3,20)$ Tingginya skor pada perlakuan R3 menunjukkan warna bokashi cenderung berwarna cokelat kehitaman dan lebih berwarna gelap dibandingkan perlakuan R2, R1 dan R0. Hasil analisis sidik ragam terhadap warna bokashi menunjukkan bahwa perlakuan lama waktu fermentasi berpengaruh sangat nyata $(\mathrm{P}<0,05)$ terhadap perubahan warna bokashi atau dengan kata lain bahwa setiap lama waktu fermentasi pada bokashi akan menghasilkan karakter warna yang berbeda. Hasil tersebut kemudian di uji lanjut dan dihasilkan bahwa perlakuan R3-R2, R3 R1, R3-R0, R2-R1, R2-R0 dan R1-R0 berbeda sangat nyata terhadap warna bokashi.

Bokashi yang semakin gelap ini menggambarkan bahwa proses fermentasi feses sapi padat dengan EM4 dengan waktu fermentasinya 35 hari berjalan dengan normal serta menunjukkan karakter bokashi yang terbaik. Hal ini sejalan dengan Djurnani et al. (2016) bahwa lama waktu fermentasi akan membuat mikroba yang bekerja juga terbatas serta perubahan warna bokashi menjadi lebih gelap dan bokashi yang sudah matang berwarna cokelat kehitaman. Sedangkan pada awal pengomposan bahan bokashi masih berwarna cokelat muda sesuai dengan warna asli bahan (feses sapi kering). Selama proses fermentasi terjadi dekomposisi pada bahan. Warna bahan bokashi berangsur menjadi cokelat muda, cokelat, hingga pada akhir proses pembokashian menjadi cokelat kehitaman, Sesuai karakteristik bokashi yang telah matang yaitu mempunyai warna cokela tua sampai kehitam-hitaman.

\subsection{Aroma Bokashi}

Seperti halnya warna, untuk mengetahui aroma bokashi yang dihasilkan dengan waktu fermentasi yang berbeda maka diberi skor dari 1-5. Tabel 2 
merupakan rataan nilai aroma bokashi dengan lama waktu fermentasi yang berbeda.

Tabel 2. Rataan Aroma Bokashi yang Difermentasi dengan Waktu Berbeda

\begin{tabular}{|c|c|c|c|c|c|c|}
\hline \multirow{2}{*}{ Perlakuan } & \multicolumn{4}{|c|}{ Ulangan } & \multirow{2}{*}{ Jumlah } & \multirow{2}{*}{ Rataan } \\
\hline & 1 & 2 & 3 & 4 & & \\
\hline R0 & 2,00 & 2,00 & 2,40 & 2,40 & 8,80 & $2,20^{\mathrm{c}}$ \\
\hline $\mathrm{R} 1$ & 3,00 & 3,20 & 3,60 & 3,60 & 13,40 & $3,35^{\mathrm{b}}$ \\
\hline $\mathrm{R} 2$ & 3,60 & 4,20 & 4,00 & 3,80 & 15,60 & $3,90^{\mathrm{a}}$ \\
\hline R3 & 3,80 & 4,00 & 4,40 & 4,40 & 16,60 & $4,15^{\mathrm{a}}$ \\
\hline Jumlah & 12,40 & 13,40 & 14,40 & 14,20 & 54,40 & \\
\hline
\end{tabular}

Ket: Angka yang diikuti superskrip yang berbeda menunjukkan pengaruh sangat nyata $(P<0,01)$.

Dari Tabel 2, secara statistik memperlihatkan perbedaan yang nyata $(\mathrm{P}<0,01)$ terhadap aroma pupuk bokashi kotoran sapi tetapi ada kecenderungan skor aroma terlihat lebih baik pada lama fermentasi $35(4,15)$ atau beraroma tanah bila dibandingkan dengan lama fermentasi $28(3,35)$ atau beraroma agak berbau tanah menuju bau tanah, kemudian waktu fermentasi $28(3,90)$ hari atau tidak beraroma tanah dan terakhir pada waktu fermentasi $14(2,20)$ atau tidak beraroma tanah dan tingkat konsentrasi yang ditunjukkan cenderung semakin menuju aroma tanah dengan waktu yang lebih lama lagi.

Menurut Isroi (2008), pupuk yang telah matang akan berbau seperti tanah, bila tercium bau yang tidak sedap berarti terjadi fermentasi anaerobik dan kompos belum matang. Yuwono (2005), menyatakan bahwa pupuk yang telah matang akan berbau seperti humus atau tanah, bila kompos berbau busuk menandakan bahwa proses dekomposisi belum selesai dan proses penguraian masih berlangsung.

\subsection{Tekstur Bokashi}

Rataan tekstur pada Tabel 3 menunjukkan bahwa rataan nilai tekstur tertinggi pada perlakuan R3(4,45/35 hari) kemudian diikuti oleh perlakuan R2 (4,15/28 hari), perlakuan R1 (2,45/21 hari) dan perlakuan R0 (2,75/14 hari). Hal ini menunjukkan ada interaksi antara tingkat lama fermentasi terhadap tekstur pupuk bokashi kotoran sapi.

Tabel 3. Rataan Tekstur Bokashi yang Difermentasi dengan Waktu Berbeda

\begin{tabular}{|c|c|c|c|c|c|c|}
\hline \multirow{2}{*}{ Perlakuan } & \multicolumn{4}{|c|}{ Ulangan } & \multirow{2}{*}{ Jumlah } & \multirow{2}{*}{ Rataan } \\
\hline & 1 & 2 & 3 & 4 & & \\
\hline R0 & 2,60 & 3,00 & 2,80 & 2,60 & 11,00 & $2,75^{b}$ \\
\hline $\mathrm{R} 1$ & 2,20 & 2,20 & 2,40 & 3,00 & 9,80 & $2,45^{\mathrm{b}}$ \\
\hline $\mathrm{R} 2$ & 4,40 & 4,00 & 4,20 & 4,00 & 16,60 & $4,15^{\mathrm{a}}$ \\
\hline R3 & 4,20 & 4,60 & 4,60 & 4,40 & 17,80 & $4,45^{\mathrm{a}}$ \\
\hline Jumlah & 13,40 & 13,80 & 14,00 & 14,00 & 55,20 & \\
\hline
\end{tabular}

Ket: Angka yang diikuti superskrip yang berbeda menunjukkan pengaruh sangat nyata $(P<0,01)$.

Dari Tabel 3, secara statistik memperlihatkan perbedaan yang tidak nyata terhadap aroma pupuk bokashi kotoran sapi. Ada kecenderungan bahwa R3 dan R2 menunjukkan hal yang sama yakni bertekstur halus. Hal ini akibat dari semakin banyaknya permukaan yang tersedia untuk bakteri pembusuk untuk menghancurkan material bokashi, seperti halnya Sutanto (2002), bahwa aktivitas mikroba berada diantara permukaan area dan udara. Permukaan area yang lebih luas akan meningkatkan kontak antara mikroba dengan bahan dan proses dekomposisi akan berjalan lebih cepat. Ukuran partikel juga menentukan besarnya ruang antar bahan (porositas). Untuk meningkatkan luas permukaan dapat dilakukan dengan memperkecil ukuran partikel bahan seperti yang dilakukan dalam penelitian ini. Bokashi yang sudah jadi memiliki tekstur remah atau tidak menggumpal (Djuarnani et al., 2006).

Perubahan tekstur dari bokashi yang awalnya tekstur keras kemudian menjadi lunak dan sudah menyerupai tekstur tanah sebab ketika diremas bokashi mengalami perubahan bentuk sangat jelas dan sudah tidak dikenali lagi bahan dasar dan hal tersebut dikarenakan aktivitas mikroorganisme yang berasal dari bahan pembuat yakni feses sapi dan EM4. Mikroorganisme yang terdapat dalam EM4 akan dengan cepat mendekomposisi bahan-bahan dalam pembuatan bokashi sehingga tekstur yang dihasilkan dari proses dekomposisi tersebut akan berangsur-angsur berubah yaitu menjadi agak menggumpal, menggumpal, sangat menggumpal hingga pada akhir proses pengomposan menjadi tidak menggumpal (remah atau mudah hancur).

\section{4. $\mathrm{pH}$}

Nilai $\mathrm{pH}$ yang dihasilkan pada semua perlakuan menunjukkan $\mathrm{pH}$ yang netral yakni tidak asam dan tidak basa. Namun, pada kontrol (R0) pH nya menunjukkan arah ke basa. Pada kondisi normal biasanya tidak akan menimbulkan masalah, selama proses fermentasi yang dilakukan dapat mempertahankan $\mathrm{pH}$ pada kisaran netral. $\mathrm{pH}$ yang netral akan membuat aktivitas mikroorganisme dalam pupuk organik berjalan sempurna, sehingga unsur hara yang terlepas dari pupuk organik juga semakin baik. Hasil sidik ragam (Anova) menunjukkan bahwa lama fermentasi bokashi 35 hari, 28 hari dan 21 hari berpengaruh nyata terhadap $\mathrm{pH}$, dibandingkan dengan bokashi yang difermentasi 14 hari. Hasil uji duncan menunjukkan bahwa R0 berbeda nyata dengan R1, R2, $\mathrm{R} 3$, dan R2 dengan R3 tidak nyata, R1 dengan R2, R3 nyata.
Tabel 4. Rataan pH Bokashi yang Difermentasi dengan Waktu Berbeda

\begin{tabular}{|c|c|c|c|c|c|c|}
\hline \multirow{2}{*}{ Perlakuan } & \multicolumn{4}{|c|}{ Ulangan } & \multirow{2}{*}{ Jumlah } & \multirow{2}{*}{ Rataan } \\
\hline & I & 2 & 3 & 4 & & \\
\hline R0 & 9,02 & 8,95 & 8,70 & 8,85 & 35,52 & $8,88^{\mathrm{a}}$ \\
\hline R1 & 7,06 & 7,10 & 7,20 & 7,05 & 28,41 & $7,10^{\mathrm{b}}$ \\
\hline $\mathrm{R} 2$ & 6,90 & 6,90 & 6,80 & 6,90 & 27,50 & $6,87^{c}$ \\
\hline R3 & 6,95 & 6,98 & 6,70 & 6,75 & 27,38 & $6,84^{\mathrm{c}}$ \\
\hline Jumlah & 29,93 & 29,93 & 29,40 & 29,55 & 118,81 & \\
\hline
\end{tabular}

Ket: Angka yang diikuti superskrip yang berbeda menunjukkan pengaruh nyata $(P<0,05)$.

Pada Tabel 4, awal fermentasi nilai pH R0 sebesar 8,88 dan pada R1,R2 $\mathrm{R} 3 \mathrm{pH}$ mengalami penurunan pada angka $\mathrm{pH}$ yang netral. Menurut Sutanto (2002), peningkatan nilai $\mathrm{pH}$ organik disebabkan karena adanya aktivitas mikroorganisme dalam dekomposer yang memberikan masukan ion $\mathrm{OH}$ dari hasil proses deorganiksi bahan organik. Hasil proses deorganiksi bahan organik oleh mikroorganisme menghasilkan ion $\mathrm{OH}$ sehingga menunjukkan peningkatan kebebasan yang selanjutnya meningkatkan nilai $\mathrm{pH}$ organik tersebut.

Fermentasi yang berjalan berhari-hari mempengaruhi perubahan $\mathrm{pH}$ pada bahan organik $\mathrm{pH}$ awal pupuk organik dimulai agak asam karena terbentuknya asam-asam organik sederhana, kemudian $\mathrm{pH}$ meningkat pada proses fermentasi lebih lanjut yang mengakibatkan terurainya protein dan terjadinya pelepasan amoniak sehingga $\mathrm{pH}$ akhir akan bermuara pada sifat yang netral. Namun demikian untuk semua perlakuan (R0, R1, R2 dan R3) nilai pH yang dihasilkan masih dalam kisaran normal berdasarkan SNI (2004) yakni 4-9.

\subsection{Nitrogen $(\mathbf{N})$}

Nitrogen pupuk bokashi yang diteliti sangat bervariasi yaitu dari sangat tinggi sampai rendah, hal ini disebabkan karena lama waktu fermentasi pupuk bokashi yang berbeda-beda. Tersedianya nitrogen dalam jumlah yang tinggi karena terjadi proses dekomposisi yang lebih sempurna, sedangkan nitrogen yang rendah disebabkan bahan baku kompos yang mengandung nitrogen rendah dan kemungkinan banyak menguap karena tidak adanya pengemasan yang sempurna terhadap bokashi. Hasil sidik ragam (Anova) menunjukkan bahwa lama fermentasi bokashi nyata $(\mathrm{P}<0,05)$ meningkatkan nitrogen. Hasil uji duncan menunjukkan bahwa : lama waktu fermentasi pada R0 berbeda nyata dengan R1, $\mathrm{R} 2, \mathrm{R} 3, \mathrm{R} 1, \mathrm{R} 2$, dan R2 dengan R3 tidak nyata, R1 dengan R3 nyata. lama fermentasi (R3) menunjukkan rata-rata $\mathrm{N}$ yang tertinggi yaitu 2,05.

Tingginya kandungan $\mathrm{N}$ dalam lama fermentasi dengan waktu 35 hari ini disebabkan lama waktu yang tersedia cukup lama untuk dekomposisi kotoran sapi, sehingga $\mathrm{N}$ dihasilkan cukup tinggi. Pada Tabel 5 juga menunjukkan bahwa semakin lama waktu fermentasi pupuk bokashi maka kandungan $\mathrm{N}$ akan semakin meningkat, hal ini terjadi karena semakin lama proses fermentasi maka proses dekomposisi yang dilakukan mikroorganisme yang menghasilkan amonia dan nitrogen (Trivana et al., 2017)

Tabel 5. Kandungan Nitrogen (N) Bokashi yang Difermentasi dengan Waktu Berbeda.

\begin{tabular}{|c|c|c|c|c|c|c|}
\hline \multirow{2}{*}{ Perlakuan } & \multicolumn{4}{|c|}{ Ulangan } & \multirow{2}{*}{ Jumlah } & \multirow{2}{*}{ Rataan } \\
\hline & $\mathrm{I}$ & 2 & 3 & 4 & & \\
\hline R0 & 1,38 & 1,21 & 1,23 & 1,39 & 5,22 & $1,30^{\mathrm{c}}$ \\
\hline $\mathrm{R} 1$ & 1,63 & 1,44 & 1,78 & 1,54 & 6,40 & $1,60^{\mathrm{b}}$ \\
\hline $\mathrm{R} 2$ & 1,86 & 1,92 & 1,73 & 1,80 & 7,32 & $1,83^{\mathrm{ab}}$ \\
\hline R3 & 2,04 & 1,60 & 2,24 & 2,35 & 8,23 & $2,05^{\mathrm{a}}$ \\
\hline Jumlah & 6,91 & 6,19 & 7,00 & 7,08 & 27,17 & \\
\hline
\end{tabular}

Ket: Angka yang diikuti superskrip yang sama menunjukkan pengaruh nyata $(P<0,05)$

\subsection{Fosfor (P)}

Fosfor mempunyai peranan dalam pembelahan sel, merangsang pertumbuhan awal pada akar, pemasakan buah, transport energi dalam sel, pembentukan buah dan produksi biji (Yulipriyanto, 2010). Untuk melihat kandungan fosfor dalam bokashi yang difermentasi dengan waktu berbeda tersaji dalam Tabel 6.

Fosfor tidak begitu bervariasi yaitu dari rendah sampai sangat tinggi. Berdasarkan nilai kualitas dari pupuk bokashi padat yang difermentasi dengan waktu yang berbeda-beda. Menurut Stofella dan Khan (2001) bahwa fosfor sangat diperlukan oleh mikroorganisme untuk membangun selnya seperti protoplasma dan inti sel. Perombakan bahan organik dan proses asimilasi fosfor terjadi karena adanya enzim fosfatase yang dihasilkan oleh sebagian mikroorganisme. Apabila jumlah mikroorganisme dalam komposan kurang maka proses perombakan bahan organik dan proses asimilasi fosfor oleh mikroorganisme juga kurang sehingga fosfor kurang termanfaatkan, begitu pun sebaliknya jika jumlah mikroorganisme dalam komposan cukup maka proses perombakan bahan organik berjalan sempurna.

Hasil sidik ragam (Anova) menunjukkan bahwa lama fermentasi bokashi berpengaruh nyata terhadap fosfor bokashi dibandingkan dengan bokashi yang difermentasi dalam waktu 14 hari (R0). Uji duncan menunjukkan bahwa perlakuan R1 dalam R2, dan R3 tidak berbeda nyata dalam meningkatkan fosfor dibandingkan dengan R0. Kandungan fosfor tertinggi pada perlakuan R2 dan R3 yaitu 0,30 . Hasil ini dikarenakan semakin lama waktu untuk fermentasi kotoran 
ternak sapi, maka fosfor yang terbentuk semakin tinggi yang diakibatkan dari fosfor yang terkandung dalam feses sapi dan tambahan dari EM4 serta kandungan $\mathrm{N}$ yang memang tinggi. Tingginya kandungan fosfor pada lama fermentasi 28 dan 35 hari juga diakibatkan karena tingginya kandungan $\mathrm{N}$ (Tabel 5), semakin tinggi kandungan $\mathrm{N}$ yang dikandung maka multiplikasi mikroorganisme yang merombak fosfor akan meningkat sehingga kandungan fosfor akan meningkat (Yuli et al., 2011).

Tabel 6. Kandungan Fosfor (P) Bokashi yang Difermentasi dengan Waktu Berbeda.

\begin{tabular}{|c|c|c|c|c|c|c|}
\hline \multirow{2}{*}{ Perlakuan } & \multicolumn{4}{|c|}{ Ulangan } & \multirow{2}{*}{ Jumlah } & \multirow{2}{*}{ Rataan } \\
\hline & I & 2 & 3 & 4 & & \\
\hline R0 & 0,13 & 0,16 & 0,15 & 0,16 & 0,62 & $0,15^{\mathrm{b}}$ \\
\hline $\mathrm{R} 1$ & 0,29 & 0,25 & 0,32 & 0,32 & 1,19 & $0,29^{\mathrm{a}}$ \\
\hline $\mathrm{R} 2$ & 0,29 & 0,32 & 0,30 & 0,32 & 1,23 & $0,30^{\mathrm{a}}$ \\
\hline R3 & 0,25 & 0,29 & 0,31 & 0,38 & 1,23 & $0,30^{\mathrm{a}}$ \\
\hline Jumlah & 0,98 & 1,03 & 1,08 & 1,18 & 4,27 & \\
\hline
\end{tabular}

Ket: Angka yang diikuti superskrip yang sama menunjukkan pengaruh nyata $(P>0,05)$

\section{7. $\quad$ Kalium (K)}

Hasil analisis kalium tidak begitu bervariasi, sama seperti kandungan pada fosfor yaitu dari rendah sampai yang tinggi. Berdasarkan nilai analisis kualitas pupuk bokashi tersebut. Sutedjo (2010) menyatakan bahwa kalium digunakan oleh mikroorganisme dalam bahan komposan sebagai katalisator, dengan kehadiran bakteri dan aktivitasnya, sangat berpengaruh terhadap peningkatan kandungan kalium. Kalium diikat dan disimpan dalam sel oleh bakteri dan jamur, jika dekomposisi kembali maka kalium akan menjadi tersedia kembali.

Hasil sidik ragam (Anova) menunjukkan bahwa lama fermentasi bokashi 35 hari $(1,23)$ berpengaruh nyata terhadap kalium bokashi dibandingkan dengan bokashi yang difermentasi 28 hari, 21 hari dan 14 hari. Kandungan K tertinggi terdapat pada lama fermentasi 35 hari dibandingkan lama fermentasi 28 hari, 21 hari dan 14 hari, hal ini dapat terjadi karena lebih banyak terbentuknya asam organik selama proses penguraian sehingga akan menyebabkan daya larut dari unsur $\mathrm{Ca}$, P dan K menjadi lebih tinggi sehingga akan lebih banyak menyediakan kalium bagi tanaman (Donahue, 1970).

Tabel 7. Kandungan Kalium (K) Bokashi yang Difermentasi dengan Waktu Berbeda.

\begin{tabular}{ccccccc}
\hline \multirow{2}{*}{ Perlakuan } & \multicolumn{7}{c}{ Ulangan } & \multirow{2}{*}{ Jumlah } & \multirow{2}{*}{ Rataan } \\
\cline { 2 - 5 } & I & 2 & 3 & 4 & & \\
\hline R0 & 1,05 & 1,03 & 1,04 & 1,05 & 4,18 & $1,04^{\mathrm{a}}$ \\
R1 & 0,91 & 1,05 & 1,22 & 0,95 & 4,13 & $1,03^{\mathrm{b}}$ \\
R2 & 0,94 & 0,98 & 0,95 & 0,92 & 3,80 & $0,95^{\mathrm{b}}$ \\
R3 & 1,20 & 1,08 & 1,38 & 1,27 & 4,94 & $1,23^{\mathrm{b}}$ \\
\hline Jumlah & 4,11 & 4,15 & 4,60 & 4,19 & 17,05 & \\
\hline
\end{tabular}

Ket: Angka yang diikuti superskrip yang sama menunjukkan pengaruh tidak nyata $(P>0,05)$.

\subsection{Rasio $\mathrm{C} / \mathrm{N}$}

Nilai rasio $\mathrm{C} / \mathrm{N}$ bahan organik merupakan faktor penting dalam pengomposan. Karbon digunakan sebagai sumber energi dan nitrogen sebagai sumber nutrisi untuk pembentukan sel-sel tubuh mikroorganisme selama proses pengomposan (Trivana et al., 2017). Berdasarkan nilai C/N rasio pupuk bokashi yang terkandung di dalam bokashi menggambarkan tingkat kematangan dari bokashi tersebut, semakin tinggi $\mathrm{C} / \mathrm{N}$ rasio berarti bokashi terurai dengan sempurna atau dengan kata lain sudah matang dan siap dijual atau dipakai sebagai pupuk. Hasil sidik ragam (Anova) menunjukkan bahwa lama fermentasi bokashi 14 hari berpengaruh sangat nyata terhadap Rasio C/N bokashi $(10,48)$ dibandingkan dengan bokashi yang difermentasi 21 hari, 28 hari dan 35 hari.

Tabel 8. Kandungan Rasio C/N Bokashi yang Difermentasi dengan Waktu Berbeda

\begin{tabular}{ccccccc}
\hline \multirow{2}{*}{ Perlakuan } & \multicolumn{7}{c}{ Ulangan } & \multirow{2}{*}{ Jumlah } & \multirow{2}{*}{ Rataan } \\
\cline { 2 - 5 } & I & 2 & 3 & 4 & & \\
\hline R0 & 9,09 & 12,53 & 10,72 & 9,58 & 41,93 & $10,48^{\mathrm{a}}$ \\
R1 & 8,55 & 9,19 & 8,87 & 8,70 & 35,32 & $8,83^{\mathrm{b}}$ \\
R2 & 7,49 & 7,26 & 7,60 & 7,50 & 29,85 & $7,46^{\mathrm{c}}$ \\
R3 & 6,95 & 8,19 & 8,20 & 8,33 & 31,68 & $7,92^{\mathrm{bc}}$ \\
\hline Jumlah & 32,09 & 37,18 & 35,39 & 34,11 & 138,78 \\
\hline
\end{tabular}

Ket: $\quad$ Angka yang diikuti superskrip yang berbeda menunjukkan pengaruh nyata $(P<0,01)$.

Dari Tabel 8 menggambarkan bahwa semakin lama waktu fermentasi pupuk bokashi maka rasio $\mathrm{C} / \mathrm{N}$ akan menurun. Hal ini disebabkan karena dalam proses fermentasi telah terjadi reaksi kimia seperti kadar $\mathrm{C}$ akan berubah menjadi $\mathrm{CO}_{2}$ dan $\mathrm{CH} 4$ yang mana merupakan gas. Mikroorganisme juga menggunakan $\mathrm{C}$ dalam bahan bahan organik (C-organik) sebagai bahan makanan sehingga $\mathrm{C}$ akan berkurang. Namun, karena proses dekomposisi bahan kompos oleh mikroorganisme yang menghasilkan amonia dan nitrogen maka kadar $\mathrm{N}$ dalam pupuk akan meningkat (Trivana et al., 2017).

\section{Simpulan}

Disimpulkan bahwa lama fermentasi pupuk bokashi padat yang berbedabeda memberikan pengaruh terhadap karakteristik fisik (warna, aroma, tekstur) dan kimia (N, P, K, Rasio C/N dan $\mathrm{pH}$ ) pupuk bokashi padat kotoran sapi. Pupuk bokashi yang paling baik adalah dengan lama fermentasi 35 hari.

\section{Pustaka}

Djuarnani, N., Kristian, Setiawan, B.S. 2006. Cara Cepat Membuat Kompos. Agromedia Pustaka. Jakarta.

Donahue, R.L.W. 1970. Soils an introduction to soil and plant growth. Prentice hall, inc. New Jersey.

Effi. 2004. Pupuk Organik, Cair \& Padat, Pembuatan dan Aplikasi. Penerbit Penebar Swadaya. Jakarta.

Isroi, 2008. Potensi biomassa lignoselulosa di Indonesia sebagai bahan baku bioethanol: Jerami padi. On Line : [diakses tanggal 03 Maret 2018].

Nasir. 2008. Pengaruh Penggunaan Pupuk Bokashi pada Pertumbuhan dan Produksi Palawija dan Sayuran. www.distperternakpandeglang.go.id. [diakses tanggal 13 April 2018].

SNI 19-7030-2004.

Sutanto, R. 2002. Penerapan Organik Pertanian. Pemasyarakatan dan Pengembangannya. Penerbit Kanisius. Jakarta.

Sutedjo, M. 2010. Pupuk dan Cara Pemupukan. Rineka Cipta. Jakarta.

Stell, R.G.D. dan J.H Torrie. 1991. Prinsip dan Prosedur Statistika Suatu Pendekatan Biometrik. PT. Gramedia Jakarta.

Stofella, P.J. dan Brian A. Khan. 2001. Compost Utilization in Holticultur. Lewis Publiser.

Trivana, L., A.Y. Pradhana., A.P. Manambangtua. 2017. Optimalisasi waktu pengomposan pupuk kandang dari kotoran kambing dan debu sabut kelapa dengan bioaktovator EM4. Jurnal sains dan teknologi lingkungan, 9 (1): 16-24.

Yuli A. Hidayati., B. Kurnani., E.T. Marlina., E. Harlia. 2011. Kualitas pupuk cair hasil pengolahan Feses Sapi Potong Menggunakan Saccharomyces cereviceae. Jurnal Ilmu Ternak, 11 (2): 104-107.

Yulipriyanto, H. 2010. Biologi tanah dan strategi pengolahannya. Graha Ilmu. Yogyakarta.

Yuwono, D. 2005. Kemampuan EM4 membuat kompos matang dalam waktu singka, ed ${ }^{1}$. Penebar Swadaya. Jakarta. 